\title{
Managerial capability for innovation for microfirms: integrating theory with empirical evidence
}

Arthur Kearney, Denis Harrington and Felicity Kelliher*

RIKON Research Group, Waterford Institute of Technology, Ireland

Abstract: The research considers a recently developed model of managerial capability for innovation in the microfirm context. Microfirms are firms employing less than 10 people. The research takes an interpretivist methodological approach based on a pilot study of five in-depth interviews with owner/managers of tourism microfirms. Findings indicate the incremental nature of innovation; the importance of aspects of managerial capability in the guise of leadership, operational capability, strategic thinking and the development of relationships with people. Innovation is shown to emerge through the interaction of aspects of managerial capability and key resource pools. The empirical research results in a refined model of managerial capability for innovation in context. A contribution to microfirm management practice is made through providing a model of managerial capability which can be used to improve the competitiveness of microfirms in the tourism industry. Allied to this contribution it is suggested that policy makers can use the model through further dissemination of their efforts to develop industry best practice. Recommendations for future empirical research based on an expanded microfirm study are suggested.

Keywords: innovation; managerial capability; microfirms

(C) De Gruyter Open Sp. z 0.0.

\section{INTRODUCTION}

This paper considers a recently developed conceptual model of managerial capability for innovation in the microfirm context (Kearney et al., 2014) and applies it to a pilot study in the tourism sector in Ireland. Microfirms are those organisations that employ less than 10 people (EU, 2010), while managerial capability may be defined as the human capability underpinning the competitiveness of the firm (Barney, 1991). This research is focused by the dynamic capabilities view of the firm (Teece et al., 1997; Winter, 2003) assuming capabilities are deeply embedded learning structures in the social fabric of the firm enabling the firm to cope proactively with change (Winter, 2003). Managerial capability comprises search mechanisms through which the manager seeks to optimise a firm's resource endowments within a framework of bounded rationality (Gavetti and Rivkin, 2007). Over time managers within an industry develop experientially based capabilities which enable them to focus attention on strategically important challenges maximising their own potential. In changing environments such as occurs in a recovering economy, dynamic managerial capabilities are capabilities through which managers 'build, integrate, and reconfigure organisational resources and competences' (Adner and Helfat, 2003: 1020). One such capability is that of innovation management.

While innovation literature offers numerous definitions, Simpson (2001) offers a theory of microfirm innovation premised on the cognitive capability of the manager. The microfirm manager is argued to shape innovation, through the shaping of new products and services, the nature of which reflects degrees of the manager's commercial experience and a creative capacity (Brouder and Eriksson, 2013). In the light of the foregoing managerial capability for innovation perspective, microfirm innovation is defined as: 
the creative use of resources and development of firm level capabilities which generates new commercial outcomes through the development of new products and services; the reconfiguration of organisational processes; and the development of new modes of market access. Inherent in this innovation is the important role of the microfirm manager, who through the development of innovation, continuously develops managerial capability for innovation.

The close links between innovation theory and the theories of dynamic capabilities suggest the study of innovation capability (Lawson and Sampson, 2001) aims to identify key managerial capabilities based on organisational processes capable of leading to innovation. In this paper, the nature of tourism microfirm innovation is investigated through the application of the proposed conceptual model (Kearney et al., 2014) in a live setting. The uniqueness of the microfirm context is argued and the authors go on to discuss the nature of product, process and market innovation as key dimensions of microfirm innovation. Reflecting the significance of the owner/manager in a microfirm setting, the nature of managerial capability is investigated with argument made for the emergence of four categories of microfirm managerial capability, which are leadership, strategic, thinking, people relationships and problem solving. Pursuing an interpretive pilot study involving semi-structured interviews with five microtourism owner/managers supported by a theme-based interview template, application of the dynamic capabilities theory coupled with empirical evidence is used to link the four categories identified in the proposed model of managerial capability for innovation to resource pools common to microfirms. Argument is made for the emergence of innovation through the interaction between managerial capability and the resource pools. In conclusion, there is discussion of key findings emerging from the pilot research study with suggestions as to the nature of future research investigation.

\section{MANAGERIAL CAPABILITY FOR INNOVATION IN TOURISM MICROFIRMS}

Tourism contributes over 200,000 jobs and over three billion euro to gross domestic product in Ireland (Failte Ireland, 2012), although the true contribution may be higher in that the industry contributes to the regional and local economy, thus spreading the benefits of economic growth more evenly (Failte Ireland, 2010). Microfirms dominate the tourism industry comprising almost ninety percent of the total population of firms (Failte Ireland, 2010). Historically, the tourism industry has adapted to changing market environments by innovating at the levels of customer service, product offerings and marketing capabilities (Camison and Montfort-Mir, 2012; Grissemann et al., 2013). Customer service levels in the tourism industry are in need of continual renewal (Failte Ireland, 2010) and existing approaches, often based on achieving minimum levels of quality are inadequate as new customers become more price conscious, less brand loyal and more sophisticated in their behaviour (Camison and Montfort-Mir, 2012).

Several strands of innovation literature concur in arguing the benefits of not studying innovation directly, instead positing the study of organisational concepts which are then related to different types of innovation. Hjalager (2010) distinguishes types of innovation in tourism firms and argues that there are five types of innovation: product, process, managerial, marketing and institutional.

- Product innovations comprise new or modified offerings within the tourism product/service. From a product offering perspective, Corrocher et al. (2009) argue, in the context of knowledge intensive microfirms, that product innovation emerges as owner/managers harness internal firm level knowledge capabilities in synchronisation with market knowledge. Thus, microfirm owner/managers are argued to play a role in product innovation, not simply through creative development of new products, but through the process of shaping a new product development mechanism in the microfirm (Freel and Robson, 2004).

- Microfirm innovation aimed at product innovation tends to overlook innovative processes underpinning market access. Corrocher et al. (2009) view process innovation as an inevitable consequence of owner/manager capability to continuously develop knowledge structures in the firm, which is often driven by new technology and comprises the altering of a firm's business processes with a view to improving overall competitive advantage. For example, process innovation can emerge through a complex interaction between owner/manager decisions to implement new technologies and deterministic impact of the wider implementation of the technologies (Barnes et al., 2012; Karjaluoto and Huhtamäki, 2010). Specifically, information technology has created many opportunities for innovative strategies in tourism (Peters and Pikkemaat, 2006), but simultaneously has challenged existing firms to radically restructure their strategic approaches (Enterprise Strategy Report Group, 2004). 
- Managerial innovation encompasses improved ways of organising and managing staff. Liberman-Yaconi et al. (2010) highlight the environmental challenges faced by microfirms seeking to innovate, and while arguing the difficulty of limited resource endowments, acknowledge the importance of managerial capability in overcoming competitiveness challenges through incremental process innovation. Kelliher and Reinl (2009) argue that the contextual nature of microfirm managerial capability results in possibilities to rethink the nature of leadership, human resource development and opportunity management. At a strategic level, there are opportunities for more creative approaches to development resulting in more innovative approaches to the long-term strategic management of the microfirm (Fuller-Love, 2006).

- Marketing innovations comprise attempts to improve the marketing capability of the firm. de Mel et al. (2009) argue microfirm innovation takes the form of new methods of marketing. Notably, customer expectations have increased as tourists expect a more sophisticated offering, even in the microfirm setting, thus marketing capability requirements have shifted. Unfortunately, tourism lags other service industries in the development of new marketing methods (Failte Ireland, 2010).

- Institutional innovations emerge as new collaborative engagements, often manifest as networks (Lynch and Morrison, 2007; Novelli et al. 2006), whereby the microfirm enhances its competitive advantage through innovative forms of collaboration.

Management development in the tourism industry faces challenges as managers embrace new levels of complexity and internationalisation (Failte Ireland, 2005). Internally, tourism industry human resource strategies are critiqued, as being inadequate leading to the depletion of human capital (Failte Ireland, 2005). Simultaneously in their external environments tourism firms face steep competitiveness challenges, amplified by the recent economic recession in Ireland (2008-2012). Rising energy costs and government charges increase the cost base of the firm and lower competitiveness by comparison with international competitors (ITIC, 2012). Limited credit availability deters long-term industry investment and hinders day-to-day management where sources of working capital have dried up (Failte Ireland, 2012). Until recently, economic stagnation and limited growth prospects both at home and in major markets have seen the demand for tourism contract (Failte Ireland, 2012), although this trend has reversed somewhat as Irish and global economies recover.

A number of contributors have posited strategic approaches to help tourism firms to benefit from the recovering economy. Cost-cutting offers the potential to create greater focus within the tourism firm, however the pursuit of overzealous cost-cutting damages deep rooted internal capability structures and breaks stakeholder ties on which competitiveness frequently relies (Novelli et al., 2006). Diversification enables the tourism firm to develop new business opportunities and counteract seasonality (Goulding et al., 2008). However, diversification frequently forces the manager outside his/her zone of capability thereby increasing the risk of business failure (Ateljevic, 2007). Critically, the development of quality systems is argued to aid competitiveness incrementally and may be ill suited to periods of rapid environmental change (Faché, 2000). Finally, competitiveness challenges can be overcome through innovation (Aldebert et al., 2010); although innovation involves considerable organisational and managerial change (Hjalager, 2010), over time it leads to longer term competitive advantage than other forms of securing competitiveness (Orfila-Sintes et al., 2005). The current reported study focuses on tourism microfirm innovation and specifically on the nature of the managerial capabilities underpinning innovation in the tourism microfirm context.

\section{A MODEL OF MICROFIRM MANAGERIAL CAPABILITY FOR INNOVATION}

This paper considers a recently developed conceptual model of managerial capability for innovation in the microfirm context (Kearney et al., 2014) by applying the principles of Figure 1 to an empirical study.

Microfirms possess characteristics including low levels of formality, a high degree of personal influence of the owner/manager on communication, limited ability to influence their business environment and limited organisational capability for specialisation (Barnes et al., 2012). The level of owner dominance is greater than in other firms as the owner plays a key operational role in the day-to-day work of the firm actively influencing employees (Kelliher and Reinl, 2009) and directly interacting with stakeholders (Phillipson et al., 2004). In the tourism industry, Marchant and Mottiar (2011) highlight how the emergence of product innovation relies on owner/manager commercial awareness and lifestyle motivation driving the business objectives. Thus, owners are argued to influence the development of 
product innovation through the process of owner/manager motivation and creativity (de Jong and Vermeulen, 2006) as outlined in Table 1.

Figure 1. Model of microfirm managerial capability for innovation. Source: Kearney et al. (2014)

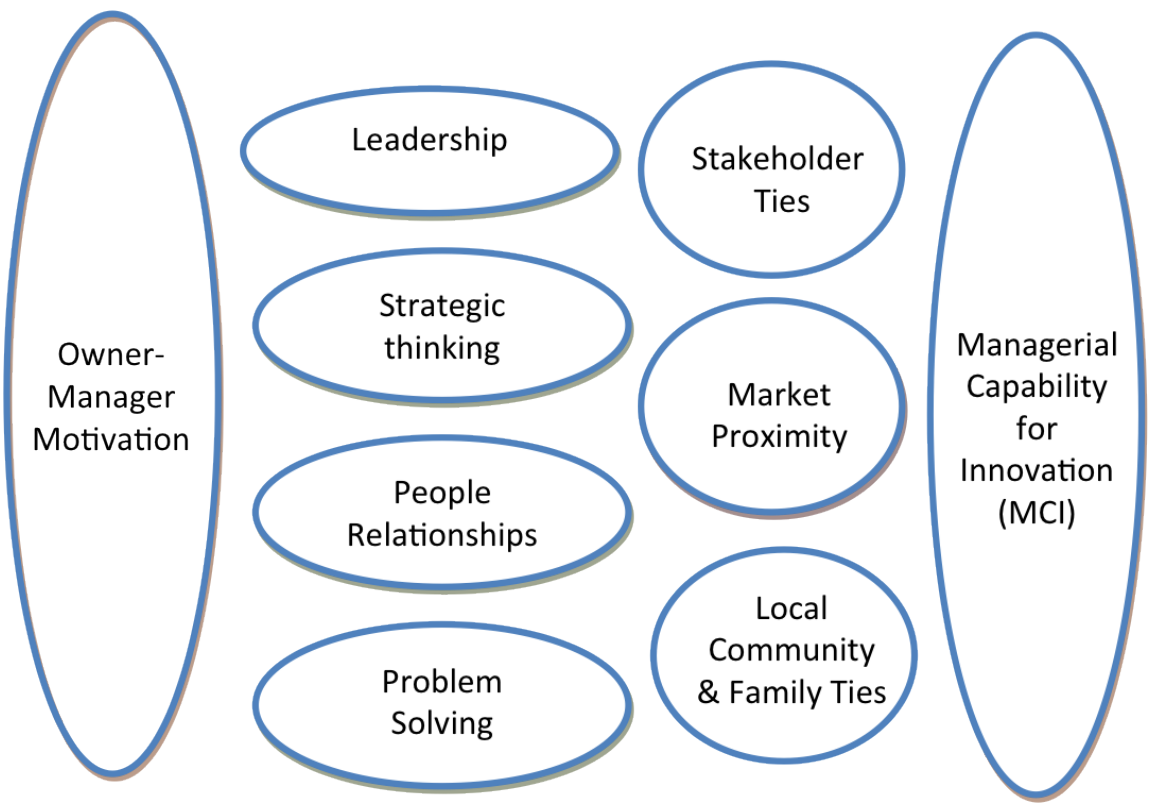

Table 1. Motivation of microfirm owner/managers

\begin{tabular}{|c|c|c|}
\hline Motivation & Nature of owner/manager motivation & Literary source \\
\hline Business philosophy & $\begin{array}{l}\text { The firm driven by business philosophy - the application of business and } \\
\text { tools to problems and a motivation based on profitability; trade off between } \\
\text { profitability and life style; changing motivation over life cycle of business }\end{array}$ & $\begin{array}{l}\text { Beaver (2007); Nybakk and Hansen } \\
\text { (2008); Phillipson et al. (2004) }\end{array}$ \\
\hline $\begin{array}{l}\text { Entrepreneurial and } \\
\text { lifestyle interaction }\end{array}$ & $\begin{array}{c}\text { Dynamic entrepreneurs based on lifestyle motivation where business concerns } \\
\text { may be secondary; niche marketing/business motivation and lifestyle motivation } \\
\text { not always in conflict - they may converge }\end{array}$ & $\begin{array}{l}\text { Ateljevic (2007); Marchant and } \\
\text { Mottiar (2011); Vaugeois and Rollins } \\
\text { (2007); Vernon et al. (2003) }\end{array}$ \\
\hline $\begin{array}{l}\text { Multiple business } \\
\text { roles }\end{array}$ & $\begin{array}{l}\text { Lifestyle motivation supports the owner/manager in multiple business roles } \\
\text { sustaining seasonality }\end{array}$ & $\begin{array}{l}\text { Baum and Szivas (2008); Carlsen } \\
\text { et al. (2008); Goulding et al. (2008) }\end{array}$ \\
\hline
\end{tabular}

When leading their business, microfirm owners approach human resource management in a primarily informal manner. Matlay (1999) describes informal recruitment mechanisms and a lack of formality in the management of human resources in a microfirm context. Similarly, Phillipson et al. (2004) argue that employees have close relationships with the owner/manager in the microfirm as the nature of the relationships emerge from a common social background rooted in a local community with a socialised awareness of the common challenges facing the microfirm. While on the surface, a microfirm's structure is simple (Devins et al., 2005), there may be divergent owner and employee interests (Matlay, 1999); although it is also argued the simpler structure offers microfirms a greater ability to develop communication (Walsh et al., 2009). The informality discussed above is also manifest as a lack of formal planning structures (Greenbank, 2000) and by a lack of desire to engage with management development which may mask relatively sophisticated managerial capabilities which are context specific (Devins et al., 2005). In context this informality is often perfectly rational behaviour given that costs of developing new marketing and management systems are both risky and expensive (Cyr et al., 2011) and often unsuitable for the microfirm context (O'Dwyer and Ryan, 2000; Reinl and Kelliher, 2010). 


\section{Categories of microfirm managerial capability for innovation}

The review of microfirm literature has seen the emergence of traits of managerial capability, which are argued to form four categories of microfirm managerial capability for innovation: leadership, strategic thinking, problem solving and people relationships (Figure 1).

Leadership enables the owner/manager to shape the ways in which organisational members construct meaning (Kruse, 1997, cited in Devins et al., 2005). Microfirm leadership is paternalistic in nature as the owner/manager's close social and physical proximity enables a profound degree of influence to be enacted. However, there are challenges in the face of personal responsibility (Oughton et al., 2003) and a sense of stakeholder responsibility (Phillipson et al., 2004). Leadership can be enhanced where the owner/manager can delegate, releasing the pressures on the owner/manager and simultaneously empowering employees (Kelliher and Reinl, 2009). Further, the process of delegation may enable the cultivation of business responsibility taken by all organisational members. However, owner/managers are challenged by tendencies to hoard power leading to potential neglect of delegation and the cultivation of a leadership style premised on fear and dominance.

Strategic thinking manifests as the ability of the owner/manager to reflect on the firm's performance (LibermanYaconi et al., 2010). Through temporary disengagement from the operational work of the firm, the owner/manager is able to inject a degree of imagination into the planning of the firm (Beaver, 2007). Strategic thinking emerges in a social context and depends on the owner/manager's social identity as a 'businessman' (O'Dwyer and Ryan, 2000: $346)$, an identity motivating and sometimes circumscribing strategic activity.

Owner/managers day-to-day work in the firm enables the evolution of experientially based problem-solving capabilities (Greenbank, 2000). The nature of the problem solving comprises a market sensing capability emerging from the close proximity and deep level of owner/manager customer interaction (Grissemann et al., 2013; O'Dwyer and Ryan, 2000). Market information is sieved in a unique way in microfirms due to the juxtaposition of the strategic and operational work in one person (Greenbank, 2000). Moreover, problem solving is based on deeply embedded intuitive patterns (Cyr et al., 2011) rendering it a potentially difficult to imitate source of competitive advantage.

The nature of the relationships between the owner/manager and people enables the development of a people management capability category. Effective dialogue is enabled with employees leading to the smoothing of conflict (Matlay, 1999). Further it becomes possible to leverage relationships with business advisors through the process of improving owner/manager people skills (Devins et al., 2005). Where the microfirm is embedded in a family context, relationships between the owner/manager and family members may be improved, potentially leveraging the family as a support for the business (Wheelock and Baines, 1998).

\section{Resource pools}

When pursuing managerial capability for innovation, microfirms are presented with three major resource pools (Figure 1): stakeholder ties; market proximity and local community and family ties. From a stakeholder perspective, managerial capability manifests as relationships with local government, suppliers and competitors, advisors and wider stakeholder connections (Devins et al., 2005; Lowik et al., 2012), each argued to impact positively on a firm's performance. Market proximity presents the owner/manager with unique opportunities to interact with and sense market developments (Kelliher and Reinl, 2009; O'Dwyer and Ryan, 2000). Furthermore, owner/managers may engage in developing new marketing methods in the microfirm (Barnes et al., 2012). The local community (Phillipson et al., 2004) and family ties (Oughton et al., 2003; Wheelock and Baines, 1998) are manifest as sources of advice, motivation and support. Local communities influence microfirms as they form a vital part of the microfirm market (Phillipson et al., 2004) supply the human resources (Matlay, 1999) and shape the social mores within which the owner/manager lives out day-to-day life. The micro firm is more heavily influenced by the local community by virtue of the limited demand it faces for more specialised, and therefore less local, labour and by the dependence of the firm on local community customers, support and advice (Phillipson et al., 2004). The family context on the microfirm has a more direct influence due to the influence of the family on strategy (Oughton et al., 2003), further enabled through the limited evolution of independent strategic decision-making processes within the firm (Greenbank, 2000).

The cumulative effect of the microfirm categories and resource pools (Figure 1) on managerial capability for innovation reflects emergent literature on microfirm innovation which focuses on product, process, marketing and owner/manager cognition. Livingstone (1971) cited in Stamp (1981) posits that managerial capability comprises 'generative thinking' ( $p .277$ ) enabling the manager to actively engage with business problems and develop solutions. 
Managerial capability is socially created as accepted beliefs about what problems managers should tackle and can solve. Within the context of microfirms, managerial capability evolves in a less formal context wherein microfirm management emerges through experience rather than being developed through formal business education and management development. Thus, the purpose of this study is to contemplate the proposed managerial capability for innovation model (Figure 1) in a live setting.

\section{METHODOLOGY}

Five pilot interviews carried out with microtourism owners are undertaken in this interpretive research study. The research objective is premised on the study of managerial capability for innovation in microfirms such that innovation is socially constructed, and based on the perceptions of owner/managers (Barrett and Sexton, 2006; Massa and Testa, 2008). The semi-structured interview places people in their social context and presents the researchers with an opportunity to develop understanding of the interviewees' perceptions of their own activities. Small and microfirm studies of innovation management highlight the importance of asking open questions such as: 'What do you mean by innovation?' (Massa and Testa, 2008: 396); 'How can you define a favourable environment for innovation?' (Massa and Testa, 2008: 396); 'What is the general motivation for firms to innovate?' (Barrett and Sexton, 2006: 343); 'What key events trigger innovation?' (Barrett and Sexton, 2006: 343); 'What is the nature of the innovation processes in the small firm?' (Barrett and Sexton, 2006: 343); 'What are the key capabilities for innovation in small firms?' (Barrett and Sexton, 2006: 343). 'What contextual factors impact on innovation?' 'Can you suggest an example of an effective policy to foster innovation?' (Massa and Testa, 2008: 396).

Taken from the emergent themes, the interview questions in this study are organised into sections dealing with specific aspects of microfirm innovation and managerial capability emerging from the literature review and exemplified in the proposed conceptual model. The use of probes ensures depth of response is achieved where a single question is likely to provoke a shorter response (Legard et al., 2003). By taking this approach, the interviewer can focus in greater depth, confident in the knowledge that all aspects of the literature reviewed will be captured in sequence (Kvale, 1996). The interviewer and interviewee come to the interview separated by different professional focus, and in a microfirm context it is argued the interviewer must facilitate the communication process through the process of bridging the communication divide by the use of language and questioning appropriate to the social world of the microfirm owner/manager (Cyr et al., 2011). Thus, the use of sections enables the interviewee to be more confident when answering, secure in the knowledge that the questions are addressing a specific topic. Moreover, the interviewer may assist by introducing each topic, thereby clarifying the overall structure and approach.

Previous academic research into the interview method argues a number of benefits of the use of pilot interviews. Language used may lead to semantic confusion and the obscuring of the intention behind the question. Question sequencing may be poor leading to poor flow of the interview and/or the time allowed for the interview may be inadequate. Simultaneously, there may be challenges in the data analysis process. Thus, the researchers can make decisions on coding the data and building or refining models from the coded data (Bazeley, 2007), as is the case in this study. There may also be challenges in dealing with live data, thus the pilot study may improve the researcher's capability to extricate data from interviewees who are reluctant to comment (Kvale, 1996). Similarly pilot interviews enable the researcher to develop awareness of communication problems, which may arise due to interviewees misunderstanding the purpose of the study (van Teijlingen and Hundley, 2010). Therefore, data analysis takes place simultaneously with data collection enabling the researcher to continually find emergent themes and to practice reflexivity throughout the research (Bazeley, 2007). Further, the emergence of new themes in the data becomes possible as the researcher engages a critical engagement with each interview as opposed to taking an overall view of the data, which may limit the emergence of patterns in the data disconfirming the researcher's theoretical expectations (Miles and Huberman, 1994). On completion of the interviews, it is possible to use across interview analysis to compare the themes and categories emerging. This approach can be used to explore the similarities and differences in answers to specific interview questions; however, caution must be taken with this approach in that, applied rigidly, it allows no scope for the emergence of themes which may not fit within the pre-existing theoretical model of managerial capability for innovation. 


\section{DISCUSSION}

Using the dynamic capabilities theory as a theoretical framework, it is argued that through the process of interaction of microfirm managerial capability categories and microfirm resources the generation of managerial capability for innovation occurs. A number of key themes emerged from the data, as highlighted in Table 2.

Table 2. Pilot study emerging findings

\begin{tabular}{|c|c|}
\hline Theme & Nature of emerging theme \\
\hline Innovation in the microfirm context & $\begin{array}{l}\text { Limited awareness by owner/managers } \\
\text { Owner/manager dominant role } \\
\text { Incremental innovation and potential for development }\end{array}$ \\
\hline $\begin{array}{l}\text { The role of the external } \\
\text { environment - articulation of } \\
\text { change }\end{array}$ & $\begin{array}{c}\text { Environmental determinism } \\
\text { Marketing technology } \\
\text { Owner/manager direct market sensing }\end{array}$ \\
\hline $\begin{array}{l}\text { Mental models and imaginative } \\
\text { strategy }\end{array}$ & $\begin{array}{c}\text { Emergence from business community } \\
\text { Surfacing of mental models } \\
\text { New markets }\end{array}$ \\
\hline $\begin{array}{l}\text { People relationships and customer } \\
\text { service }\end{array}$ & $\begin{array}{c}\text { Owner/manager shares local expertise } \\
\text { Owner/manager shares hobby } \\
\text { Owner/manager symbolic representation of firm }\end{array}$ \\
\hline Operational capability & $\begin{array}{l}\text { Opportunities through craft capability and market sensing via market proximity } \\
\text { Challenges of over immersion in operational work to neglect of strategy }\end{array}$ \\
\hline Nature of micro firm leadership & $\begin{array}{c}\text { Culture shaping limited evidence/possibly tacit in nature } \\
\text { Paternalism utilising employees as resource } \\
\text { Delegation - limits and opportunities } \\
\text { Resilience }\end{array}$ \\
\hline Resource pools & $\begin{array}{l}\text { Family as potential resource yet barrier to innovation } \\
\text { Gap between policy makers and owner/managers } \\
\text { Resource limits and limited managerial capability to leverage resources } \\
\text { Stakeholder ties and opportunities and limits }\end{array}$ \\
\hline
\end{tabular}

In a number of interviews, there is a level of difficulty in answering questions as to the nature of innovation, suggesting interviewees may experience difficulty surfacing an understanding of the concept. Findings also indicate owner/managers perceive themselves as playing the dominant role in managing innovation in the microfirm (Simpson, 2001). The respondents point to innovation as an incremental tool and related to improvement and they argue that incremental innovation brings satisfaction and business benefits in terms of differentiating the firm. The strategic management of innovation is found to be primarily implicit in nature and takes place both incrementally and in larger steps, with the former part of operational work and the latter taking place, more occasionally and perhaps driven by environmental contingencies, where the owner/manager perceives the need to act based on perceptions of environmental change (Liberman-Yaconi et al., 2010). Product innovation is considered important by a number of owner/managers (Corrocher et al., 2009), ranging from simple adjustments to culinary offerings to more advanced forms of product development such as package deals. There is little evidence of process innovation, and there are limitations in managerial interaction around technology across the sample of firms. While a number of interviewees express enthusiasm towards technology and show signs of utilising technology in their businesses, a strategic perspective is lacking with regard to an integrated approach to marketing.

The external environment is given importance by the interviewees as a constraining force and some consider the limits of the local environment in terms of not being part of a heavily promoted tourism region as a particular problem. The nature of externally created innovation is argued to limit the owner/manager's potential regarding innovation, and such needs are met with relatively conservative responses in the interviewee firms. The direct contact between the owner/manager and the market in day-to-day operations of the firms provides an opportunity to articulate change and innovation, through direct sensing of the market (O'Dwyer and Ryan, 2000). In many of the firms sampled, the owner/managers exhibit an awareness of the market (Camison and Montfort-Mir, 2012) and 
some interviewees provide evidence supporting the opportunity to differentiate the firm from competitors through levels of guest interaction and yet each appear limited in terms of developing techniques to perform market analysis. This is further articulated by interviewees who describe 'fire fighting' where problems are detected and solved but rarely in a form where underlying strategic imbalances are challenged. There are perceptions that key contacts can be a source of advice leading to innovation in the microfirm; for example a family member advises and motivates interviewee 4; however, there is limited evidence in the interviews of interaction between owner/managers and stakeholder ties which surfaces mental models. Finally, in leadership terms, there is limited evidence of owner/ managers shaping culture, although interviewee 5 gives examples of actively encouraging employees to talk with and listen to guests, as part of building relationships with customers (Grissemann et al., 2013). The findings also suggest owner/managers are reluctant to delegate both because they wish to be seen to be the face of their firm, from the guest's perspective and because of perceived limited capabilities of often part time staff.

With reference to the resource pools, many of the interviewees perceive the importance of ties to competitors as a form of business referral (Phillipson et al., 2004); however, engagement with ties remains limited in many of the firms. Many of the microfirms involved a degree of joint husband and wife involvement in the management of the firm and these personal/family ties were exhibited throughout the findings. The owner/managers believe they have a good understanding of the financial aspect of managing their firms, with examples in the analysis of hotel industry costs provided by interviewees 2 and 5 . However, lifestyle motivation and the nature of the 'home' that is also the micro hotel may play a part, with interviewee 1 expressing contentment with lower levels of innovation than possible, by his own admission. Contemplating Figure 1 in light of the pilot findings, the authors sought to refine the model of managerial capability for innovation to reflect the emerging themes identified in the empirical study (Table 2). In the resultant managerial capability for innovation model (Figure 2), the microfirm market environment forms the outer circle. It bounds and interacts with stakeholder environments, shaping and to an extent being shaped by these interactions. Inside this boundary is the near environment, within which endowments such as the family and stakeholder ties are found. The subsequent circle illustrates the owner/manager who resides at the core of the firm reflecting their pivotal role in seeking out and promoting innovation; the innermost circle being the source of managerial capability for innovation. Thus, the model of microfirm managerial capability for innovation depicts an environment where the organisation can almost be visualised as a brain (Morgan, 1986).

Figure 2. Refined model of microfirm managerial capability for innovation

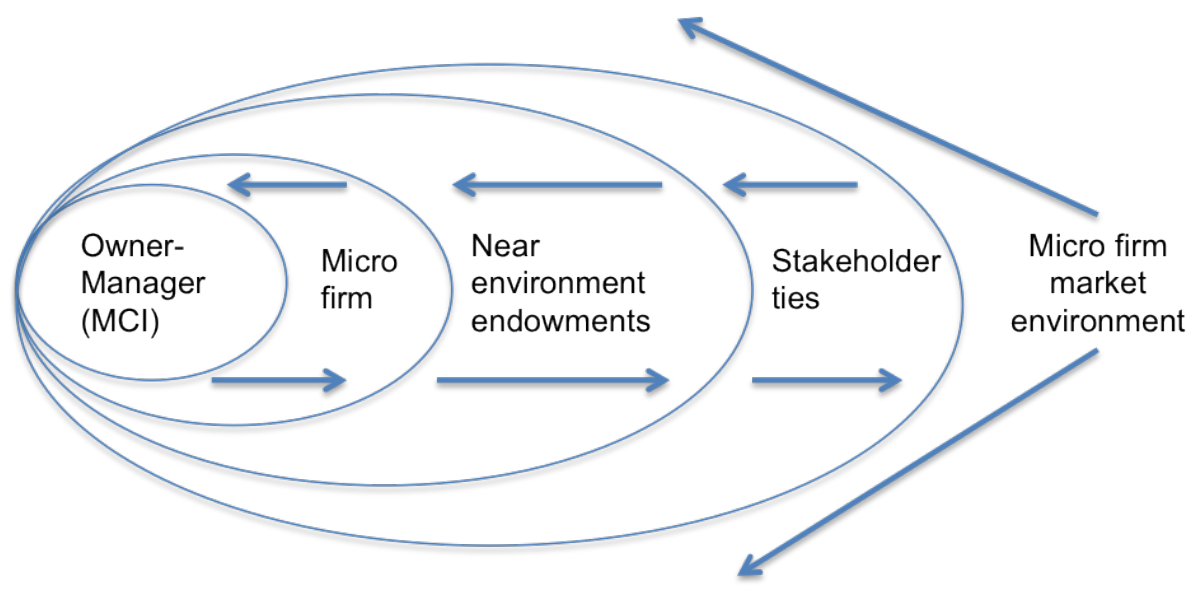

The owner/manager's managerial capability for innovation $(\mathrm{MCl})$ is shaped by these environments (Figure 2) and although the owner/manager is closest to the internal environment of the microfirm, this does not imply this environment influences innovation capability most. Innovation capability depends on people relationship communication mechanisms, which are established throughout the various environments. The strategic thinking capability is internal to the owner/manager but can be developed through interaction with an appropriate environment and strategic thinking helps to shape the owner/manager's interaction with the near and outer external environments, towards building managerial capability for innovation. This model is not an input/output model rather it portrays a steady state of the nature of microtourism firm managerial capability for innovation, leading to potential difficulties whereby the owner/manager's managerial capability may be environmentally determined. 


\section{CONCLUSION}

An integration of preceding research and empirical evidence has enabled the development of theoretical insight into the nature of microtourism firm managerial capability for innovation. In the microfirm context, Simpson (2001) argues the need for greater research into the nature of microfirm innovation and specifically the nature of managerial capabilities enabling innovation. There are arguments that innovation in the microfirm context may be externally driven, for example by technology or through links to advanced processes in supplier firms. However, even where these arguments are relevant, a level of managerial capability for innovation is necessary to contextualise and commercialise the innovation in the microfirm context, while Thomas et al. (2011) argue the need for greater research into both the nature of microtourism firm innovation and the managerial capabilities underpinning innovation.

Taking cognisance of the unique contextual nature of microfirm innovation this paper contributes to the development of greater understanding of microfirm innovation. In addition to addressing a gap in the academic literature, the research may benefit microfirm owner/managers, practitioners and tourism stakeholders by exposing them to a model of managerial capability for innovation specific to their industry and firm context for the first time. Given the high numbers of microfirms in the tourism industry and the deep nature of policy/industry links, the potential impact at industry level is considerable. Closely related to this benefit, policy makers may be able to disseminate the model through their industry links with tourism firms and to improve managerial practice and competitiveness across the industry. Future empirical research might profitably use a qualitative methodology to better investigate the complex and embedded nature of microfirm managerial capability in the tourism context. Given the dominant role played by the owner/manager future research might use in depth interviews to gain greater perspective on the perceptions of these key informants.

\section{References}

Adner, R. and Helfat, C. (2003). 'Corporate effects and dynamic managerial capabilities'. Strategic Management Journal, 24: 11, 1011-1025.

Aldebert, B., Dang, R. and Longhi, C. (2010). 'Innovation in the tourism industry'. Tourism Management, 30: $1,1-10$.

Ateljevic, J. (2007). 'Small tourism firms and management practices in New Zealand: The Centre Stage Macro Region'. Tourism Management, 28: 1, 307-316.

Barnes, D., Clear, F., Dyerson, R., Harindranath, G., Harris, L. and Rae, A. (2012). 'Web 2.0 and microbusinesses: An exploratory investigation'. Journal of Small Business and Enterprise Development, 19: 4, 687-711.

Barney, J. (1991). 'Firm resources and sustained competitive advantage'. Journal of Management, 17: 1, 99-120.

Barrett, P. and Sexton, M. (2006). 'Innovation in small project based construction firm'. British Journal of Management, 17: 4, 331-346.

Baum, T. and Szivas, E. (2008). 'HRD in tourism: A role for government'. Tourism Management, 29: 4, 783-794.

Bazeley, P. (2007). Qualitative data analysis with NVivo, London: Sage.

Beaver, G. (2007). 'The strategy payoff for smaller enterprise'. The Journal of Business Strategy, 28: $1,11-17$.
Brouder, P. and Eriksson, R. (2013). 'Staying power: What influences micro firm survival in tourism'. Tourism Geographies, 15: 1, 125-144.

Camison, C. and Montfort-Mir, V. (2012). 'Measuring innovation in tourism'. Tourism Management, 33: 4, 776-789.

Carlsen, J., Morrison, A. and Weber, P. (2008). 'Lifestyle oriented small tourism firms'. Tourism Recreation Research, 33: 3, 255-263.

Corrocher, N., Cusmano, L. and Morrison, A. (2009). 'Modes of innovation in knowledge intensive business services: Evidence from Lombardy'. Journal of Evolutionary Economics, 19: 2, 173196.

Cyr, A., Meier, O. and Pacitto, J. (2011). "'Method in their madness": Understanding the behaviour of VSE owner-managers'. Journal of Small Business and Enterprise Development, 18: 2, 331-351.

de Jong, J. and Vermeulen, P. (2006). 'Determinants of product innovation in small firms: A comparison across industries'. International Small Business Journal, 24: 6, 587-609.

de Mel, S., McKenzie, D. and Woodruff, C. (2009). 'Innovative firms or innovative owners: Determinants of innovation in micro, small and medium sized enterprises'. IZA Discussion paper 3962, 139-147. 
Devins, D., Gold, J., Johnson, S. and Holden, R. (2005). 'A conceptual model of management learning in micro businesses'. Education and Training, 47: 8-9, 540-551.

Enterprise Strategy Review Group. (2004). Report of Enterprise Strategy Review Group. http://www. forfas.ie/publications [Accessed 11 May 2013].

EU (2010). Small and medium sized enterprises-craft and micro enterprises. http://ec.europa.eu/enterprise/ policies/sme/promoting-entrepreneurship/craftsmicroenterprises [Accessed 24 October 2011].

Faché, W. (2000). 'Methodologies for innovation and improvement of services in tourism'. Managing Service Quality, 10: 6, 356-366.

Failte Ireland. (2005). Competing through people: a human resource strategy for tourism. http://www. failteireland.ie/informationcentre [Accessed 15 May 2013].

Failte Ireland. (2010). Fostering an innovation culture in Irish tourism: A summary paper. http://www. failteireland.ie/Information-Centre/Publications/ Reviews---Reports/Policy/Innovation Paper_22-12-2009 [Accessed 18 February 2014].

Failte Ireland. (2012). Annual Report. http://www. failteireland.ie/informationcentre [Accessed 20 August 2012].

Freel, M. and Robson, P. (2004). 'Small firm innovation, growth and performance: Evidence from Scotland and Northern England'. International Small Business Journal, 22: 6, 561-575.

Fuller-Love, N. (2006). 'Management development in small firms'. International Journal of Management Reviews, 8: 3, 175-190.

Gavetti, G. and Rivkin, J.W. (2007). 'On the origin of strategy: Action and cognition over time'. Organization Science, 18: 3, 420-439.

Goulding, P.J., Baum, T.G. and Morrison, A.J. (2008). 'Seasonal trading and lifestyle motivation: Experiences of small tourism businesses in Scotland'. Journal of Quality Assurance in Hospitality \& Tourism, 5: 2-4, 209-238.

Greenbank, P. (2000). 'Training micro-business ownermanagers: A challenge to current approaches'. Journal of European Industrial Training, 24: 7, 403411.

Grissemann, U., Plank, A. and Brunner-Sperdin, A. (2013). 'Enhancing business performance of hotels: The role of innovation and customer orientation'. International Journal of Hospitality Management, 33: 1, 347-356.

Hjalager, A. (2010). 'A review of innovation research in tourism'. Tourism Management, 31: 2, 1-12.

Irish Tourism Industry Confederation (ITIC). (2012).
Analysis of CSO data. http://www.itic.ie/reports [Accessed 10 June 2013].

Karjaluoto, H. and Huhtamäki, M. (2010). 'The role of electronic channels in micro-sized brickand-mortar firms'. Journal of Small Business \& Entrepreneurship, 23: 1, 17-38.

Kearney, A., Harrington, D. and Kelliher, F. (2014). 'Exploiting managerial capability for innovation in a microfirm context: New and emerging perspectives within the Irish hotel industry'. European Journal of Training and Development, 38: 1-2, 95-118.

Kelliher, F. and Reinl, L. (2009). 'A resource based view of micro firm management practice'. Journal of Small Business and Enterprise Development, 16: 3, 521-532.

Kvale, S. (1996). Interviews: An introduction to qualitative research interviewing, Thousand Oaks, CA: Sage.

Lawson, B. and Sampson, D. (2001). 'Developing innovation capability in organisations: A dynamic capabilities approach'. International Journal of Innovation Management, 5: 3, 377-397.

Legard, R., Keegan, J. and Ward, K. (2003). 'In-depth interviews', in J. Ritchie and J. Lewis (eds), Qualitative Research Practice: A Guide for Social Science Students and Researchers, London: Sage, 138-169.

Liberman-Yaconi, L., Hooper, T. and Hutchings, K. (2010). 'Towards a model of understanding strategic decision making in micro firms: Exploring the Australian information technology sector'. Journal of Small Business Management, 48: 1, 70-95.

Lowik, S., Van Rossum, D., Kraaijenbrink, J. and Groen, A. (2012). 'Strong ties as sources of new knowledge: How small firms innovate through bridging capabilities'. Journal of Small Business Management, 50: 2, 239-256.

Lynch, P. and Morrison, A. (2007). 'The role of networks', in E. Michael, Micro-Clusters and Networks in Micro-clusters and Networks: The Growth of Tourism, Amsterdam: Elsevier, 43-62.

Marchant, B. and Mottiar, Z. (2011). 'Understanding lifestyle entrepreneurs and digging beneath the issue of profits: Profiling surf tourism lifestyle entrepreneurs in Ireland'. Tourism Planning \& Development, 8: 2, 171-183.

Massa, S. and Testa, S. (2008). 'Innovation and SMEs: Misaligned perspectives and goals among entrepreneurs, academics, and policy makers'. Technovation, 28: 7, 393-407.

Matlay, H. (1999). 'Employee relations in small firms: A micro business perspective'. Employee Relations, 21: 3, 285-295.

Miles, M.B. and Huberman, A.M. (1994). Qualitative data analysis: An expanded sourcebook, London: Sage. 
Morgan, G. (1986). Images of Organisation, Thousand Oaks: Sage.

Novelli, M., Schmitz, B. and Spencer, T. (2006). 'Networks, clusters and innovation in tourism: A U.K. experience'. Tourism Management, 27: 6, 1141-1152.

Nybakk, E. and Hansen, E. (2008). 'Entrepreneurial attitude, innovation and performance among Norwegian nature based tourism enterprises'. Forest Policy and Economics, 10: 7, 473-479.

O'Dwyer, M. and Ryan, E. (2000). 'Management development issues for owners/managers of micro-enterprises'. European Journal of Industrial Training, 24: 6, 345-353.

Orfila-Sintes, F., Crespi-Cladera, R. and Martinez-Ros, E. (2005). 'Innovation activity in the hotel industry: Evidence from the Balearic islands'. Tourism Management, 26: 6, 851-865.

Oughton, E., Wheelock, J. and Baines, S. (2003). 'Micro businesses and social inclusion in rural households: A comparative analysis'. Sociologica Ruralis, 43: 4, 331-348.

Peters, M. and Pikkemaat, B. (2006). 'Innovation in tourism'. Journal of Quality Assurance in Hospitality \& Tourism, 6: 3-4, 1-6.

Phillipson, J., Bennett, K., Lowe, P. and Raley, M. (2004). 'Adaptive responses and asset strategies: The experience of rural micro firms and Foot and Mouth Disease'. Journal of Rural Studies, 20: 2, 227-243.

Reinl, L. and Kelliher, F. (2010). 'Co-operative micro firm strategies: Leveraging resources through learning networks'. The International Journal of Entrepreneurship and Innovation, 11: 2, 141150 .
Simpson, B. (2001). 'Innovation and the micro enterprise'. International Journal of Services Technology and Management, 2: 3, 377-387.

Stamp, G. (1981). 'Levels and types of managerial capability'. Journal of Management Studies, 18: 3, 277-298.

Teece, D., Pisano, G. and Shuen, A. (1997). 'Dynamic capabilities and strategic management'. Strategic Management Journal, 18: 7, 509-533.

Thomas, R., Shaw, G. and Page, S. (2011). 'Understanding small firms in tourism: A perspective on research trends and challenges'. Tourism Management, 30: 1, 1-14.

van Teijlingen, E. and Hundley, V. (2001). 'The importance of pilot studies'. Social Research. UK: University of Bournemouth.

Vaugeois, N. and Rollins, R. (2007). 'Mobility into tourism: Refuge employer'. Annals of Tourism Research, 34: 3, 630-648.

Vernon, J., Essex, S., Pinder, D. and Curry, K. (2003). "The "greening" of tourism micro busineses: Outcomes of focus group investigations in South East Cornwall'. Business Strategy and the Environment, 12: 1, 49-69.

Walsh, M., Lynch, P. and Harrington, D. (2009). 'A proposed model of firm level innovativeness: The small tourism firm'. Tourism and Hospitality in Ireland Conference (THRIC). Dublin Institute of Technology Dublin.

Wheelock, J. and Baines, S. (1998). 'Working for each other: Household and micro business survival and growth'. International Small Business Journal, 17: 1, 16-35.

Winter, S. (2003). 'Understanding dynamic capabilities'. Strategic Management Journal, 24: 10, 991-995. 